\title{
Note
}

\section{Marine Mammal and Sea Turtle Sightings During a Survey of the Endeavour Segment of the Juan de Fuca Ridge, British Columbia}

\author{
MeIKe Holst
}

LGL Limited, environmental research associates, 9768 Second Street, Sidney, British Columbia V8L 3Y8 Canada; email: mholst@1gl.com

Holst, Meike. 2017. Marine mammal and sea turtle sightings during a survey of the Endeavour Segment of the Juan de Fuca Ridge, British Columbia. Canadian Field-Naturalist 131(2): 120-124. https://doi.org/10.22621/cfn.v131i2.1873

Marine mammals and sea turtles were documented as part of a monitoring and mitigation program during a seismic study offshore $(\sim 250 \mathrm{~km})$ from Vancouver Island, British Columbia, during August-September 2009. Forty-one marine mammals in nine groups were sighted. Dall's Porpoise (Phocoenoides dalli) was the most frequently sighted species. A Sperm Whale (Physeter macrocephalus), a pod of Pacific White-sided Dolphins (Lagenorhynchus obliquidens), an unidentified toothed whale, a Northern Elephant Seal (Mirounga angustirostris), and a Leatherback Turtle (Dermochelys coriacea) were also observed. These data augment current knowledge on the occurrence of marine mammals and sea turtles in the offshore waters of British Columbia.

Key Words: Dall's Porpoise; Phocoenoides dalli; Leatherback Turtle; Dermochelys coriacea; Northern Elephant Seal; Mirounga angustirostris; Sperm Whale; Physeter macrocephalus; Pacific White-sided Dolphins; Lagenorhynchus obliquidens; seismic survey; marine mammal; Vancouver Island; British Columbia; Endeavour Hydrothermal Vent Marine Protected Area

\section{Introduction}

Limited information is available on the occurrence and distribution of marine mammals and sea turtles inhabiting the offshore waters of British Columbia. Although marine mammal surveys have taken place in deep offshore waters out to the edge of the exclusive economic zone approximately 200 nautical miles off the coast of Washington (e.g., Barlow and Forney 2007; Barlow 2016), surveys have generally not occurred that far offshore in Pacific waters of Canada. Surveys by Fisheries and Oceans Canada off British Columbia have typically occurred within $50 \mathrm{~km}$ of the shelf break and did not extend more than $150 \mathrm{~km}$ offshore (Ford et al. 2010); the most frequently sighted species were Humpback Whale (Megaptera novaeangliae), Fin Whale (Balaenoptera physalus), Pacific White-sided Dolphin (Lagenorhynchus obliquidens), and Dall's Porpoise (Phocoenoides dalli). In addition, systematic surveys have taken place in inshore coastal waters (e.g., Williams and Thomas 2007; Best et al. 2015). Opportunistic sightings in offshore waters have also been reported to the British Columbia Cetacean Sightings Network (BCCSN), but these records are not corrected for effort.

As part of the marine mammal monitoring and mitigation program for Lamont-Doherty Earth Observatory's Endeavour Tomography (ETOMO) experiment, biologists watched for marine mammals and sea turtles in and adjacent to the Endeavour Hydrothermal Vent Marine Protected Area (EHV MPA) during an academic seismic survey in August-September 2009. The EHV MPA is a unique ecosystem consisting of hydrothermal vents and associated fauna located $\sim 250 \mathrm{~km}$ southwest of Vancouver Island, British Columbia. It covers $\sim 93$ $\mathrm{km}^{2}$ and lies in water $\sim 2250 \mathrm{~m}$ deep. The increased con- centration of vent-derived material in the EHV MPA is likely enhancing the abundance of zooplankton there, leading, in turn, to increased productivity throughout the entire water column above the venting region (Tunnicliffe and Thomson 1999). However, it is uncertain whether this translates into higher densities of marine mammals and sea turtles above the vent fields (Gisiner et al. 2009; Soule et al. 2009).

This study was not designed as a systematic marine mammal and sea turtle survey, but rather as part of a program to reduce the possible effects of seismic survey operations on marine animals. Nonetheless, it allowed for determination of encounter rates and contributes to our understanding of the occurrence and distribution of cetaceans, pinnipeds, and turtles in deep, offshore waters of British Columbia.

\section{Methods}

The ETOMO experiment took place in and around the EHV MPA, located $250 \mathrm{~km}$ southwest of Vancouver Island, British Columbia, within the area bounded by $47^{\circ}-49^{\circ} \mathrm{N}$ and $127^{\circ} 30^{\prime}-130^{\circ} \mathrm{W}$ (Figure 1). The seismic vessel Marcus G. Langseth left Astoria, Oregon, on 22 August 2009. During the study, a 36-airgun array with a total discharge volume of $6600 \mathrm{in}^{3}\left(108155 \mathrm{~cm}^{3}\right)$ was towed behind the Langseth. The source array had an acoustic output (downward) of $259 \mathrm{~dB}$ re $1 \mu \mathrm{Pa} \mathrm{m}$ zeroto-peak . A brief $(\sim 0.1 \mathrm{~s})$ pulse of sound was emitted every $\sim 250-500 \mathrm{~m}$ along designated transect lines. Airgun operations occurred day and night on a daily basis starting on 26 August and concluding on 11 September. During seismic acquisition, the vessel traveled $7-9 \mathrm{~km} / \mathrm{h}$; when not towing gear (e.g., during transits to the study area), the Langseth cruised at $20-24 \mathrm{~km} / \mathrm{h}$. Water depth in the survey area was $>2000 \mathrm{~m}$. 


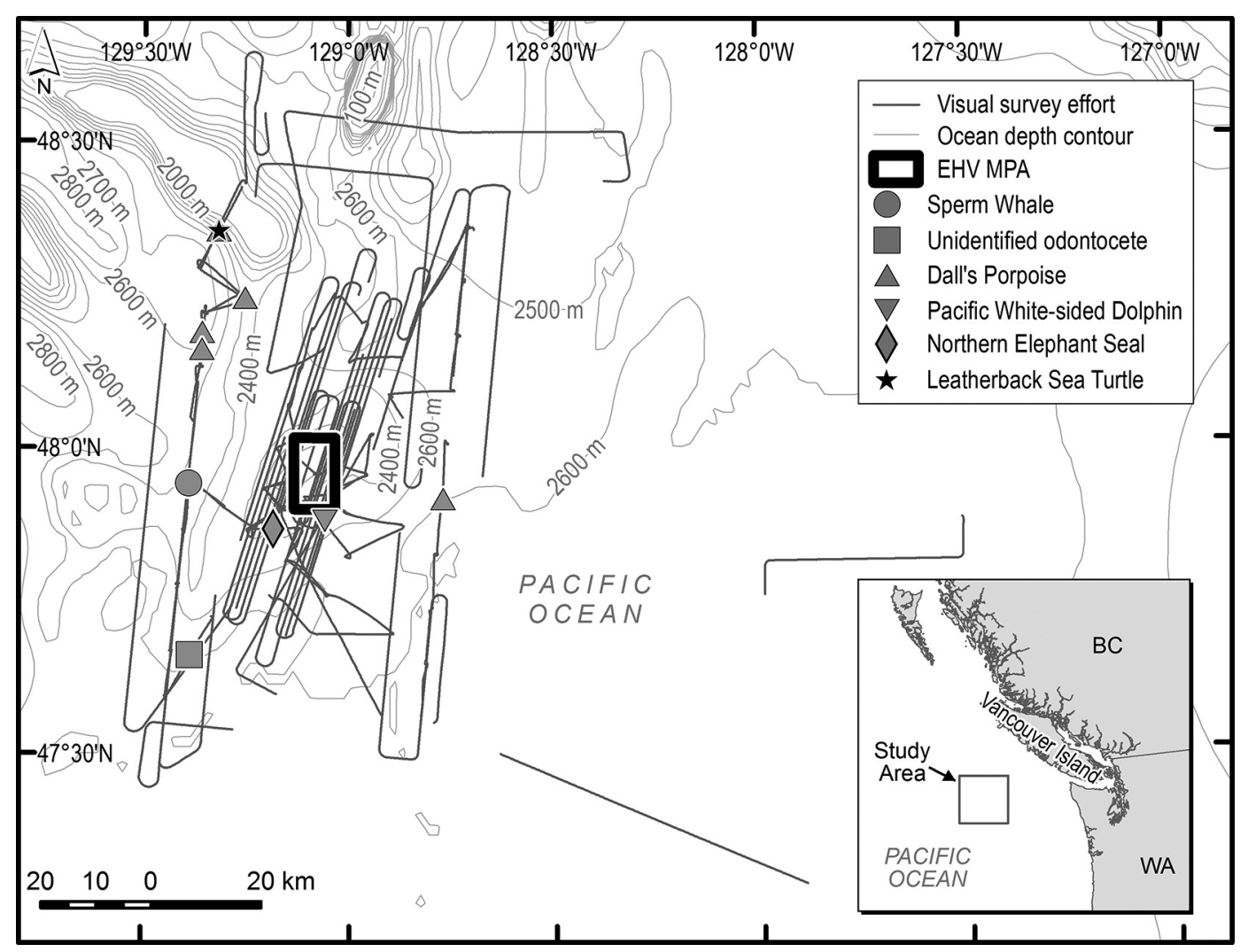

FIgURE 1. The Endeavour Tomography survey area showing observation effort and sightings of marine mammals and a sea turtle, 23 August to 18 September 2009. Note: EHV MPA = Endeavour Hydrothermal Vent Marine Protected Area.

Standard monitoring and mitigation measures were implemented during the study, including ramp-up, power-down, and shut-down procedures (e.g., Nowacek et al. 2013; Wright and Cosentino 2015). Visual observations commenced 23 August and continued until 18 September. One or two experienced observers (out of a team of six) watched for marine mammals and sea turtles from approximately 0700 to 2030 from the Langseth's observation tower, $\sim 20 \mathrm{~m}$ above sea level. Observers were on watch for shifts no longer than $4 \mathrm{~h}$. The observers used $7 \times 50$ reticle binoculars, $25 \times 150$ big-eye binoculars, and the naked eye to look for marine mammals and sea turtles around the vessel. While on watch, observers kept written records of environmental conditions and vessel activities every $30 \mathrm{~min}-$ utes. For each sighting, species, identification reliability, number of individuals, environmental conditions (glare, visibility, Beaufort wind force), date, time, and vessel position and activity were recorded on a datasheet.

Encounter rates (number of sightings per $1000 \mathrm{~km}$ surveyed and number of individuals per $1000 \mathrm{~km}$ ) were determined for all species seen during periods without airgun activity. These "non-seismic" periods included only data collected before or more than $6 \mathrm{~h}$ after seismic operations had ceased; the 6-h period was used to distinguish seismic periods from those periods where seismic surveys were sufficiently far in the past that it could be assumed that they had no residual effect on current animal behaviour or distribution. In addition, only data obtained during Beaufort wind force $\leq 5$ and when the vessel travelled at speeds over $3.7 \mathrm{~km} / \mathrm{h}$ were used to determine encounter rates.

\section{Results}

The ETOMO experiment included $330 \mathrm{~h}$ of observations covering $\sim 2714 \mathrm{~km} ; 121 \mathrm{~h}$ of observations $(\sim 1036 \mathrm{~km})$ took place during periods when the seismic source was not operating, and the remaining effort occurred when airguns were operational. During nonseismic periods, nearly half of all observations $(47 \%)$ were made by one observer; the remainder were made by two observers. Although the variable number of observers introduced a source of bias, we did not correct for it. Most observation effort (67\%) occurred during Beaufort wind force $\leq 4$.

A total of 41 marine mammals in nine groups were sighted; none were seen within the EHV MPA (Figure 1). Dall's Porpoise was the most frequently sighted spe- 
cies (five groups totalling 28 individuals); a Sperm Whale (Physeter macrocephalus), a pod of ten Pacific White-sided Dolphins, one unidentified odontocete, and one Northern Elephant Seal (Mirounga angustirostris) were also observed. In addition, one Leatherback Sea Turtle (Dermochelys coriacea) was seen. Except for the pod of Pacific White-sided Dolphins, which was observed on 25 August before seismic operations commenced, all sightings were made during September after all airgun activity had ceased. Thus, all sightings occurred during non-seismic periods. The encounter rate was highest for Dall's Porpoise (5.0 groups $/ 1000 \mathrm{~km}$ surveyed or 31.4 individuals $/ 1000 \mathrm{~km})$; the encounter rate for Pacific White-sided Dolphin was 16.5 individuals $/ 1000 \mathrm{~km}$. All other species were encountered at a rate of 1.7 groups $/ 1000 \mathrm{~km}$.

\section{Discussion}

Although the ETOMO experiment was designed to obtain information on the sub-seafloor structure of volcanic and hydrothermal features that form as a result of movements of the Earth's tectonic plates, useful information on the occurrence of marine mammals and a sea turtle in the area was also collected. Numerous sightings of Leatherback Turtles have been made throughout the waters of British Columbia, including offshore from Vancouver Island (McAlpine et al. 2004; Pacific Leatherback Turtle Recovery Team 2006; Spaven et al. 2009). Our sighting on 11 September is one of the farthest offshore observations - if not the farthest - reported for British Columbia. Most other reported sightings have occurred in August, followed by September (Spaven et al. 2009). Sightings of Leatherback Turtles have also been made off Washington in 1989 and 1990; most turtles occurred in continental slope waters, although some were found over the shelf (Green et al. 1992). During that study, all sightings were reported for June-September, with most in July.

There is a lack of information on the at-sea distribution of Northern Elephant Seals in British Columbia (Best et al. 2015). However, Elephant Seals are known to transit through the offshore waters of Vancouver Island, including our study area, as they move between southern rookeries and northern feeding areas (e.g., Le Boeuf et al. 2000; Ganong 2012; Robinson et al. 2012). Elephant Seals and Northern Fur Seals (Callorhinus ursinus) have been seen in the deep offshore waters of British Columbia and Washington (Bonnell et al. 1992; Ford 2014). Steller Sea Lions (Eumetopias jubatus) have been sighted in coastal waters of British Columbia (Ford 2014) and in shelf and slope waters of Washington (Bonnell et al. 1992).

Based on information from sightings in the offshore waters of Washington (e.g., Green et al. 1992; Barlow and Forney 2007; Becker et al. 2014; Barlow 2016),
Dall's Porpoises, Pacific White-sided Dolphins, Northern Right Whale Dolphins (Lissodelphis borealis), and Risso's Dolphins (Grampus griseus) were expected to be common in the ETOMO study area. Dall's Porpoise and Pacific White-sided Dolphin have been reported most often in this area, based on opportunistic sightings found in the BCCSN database ${ }^{1}$, with more than 25 sightings each, followed by Fin and Humpback Whales with fewer than ten sightings each (BCCSN, unpublished data 1956-2015). The encounter rates (number per $1000 \mathrm{~km}$ ) for Pacific White-sided Dolphin and Dall's Porpoise derived from the ETOMO study were greater than those for offshore areas of Washington, where 3.28.2 and $1.6-4.6 / 1000 \mathrm{~km}$ were found during summer and fall, respectively (Green et al. 1992).

In contrast to expectations based on surveys off Washington, only four sightings of Northern Right Whale Dolphins and no Risso's Dolphins were made in the ETOMO study area (BCCSN, unpublished data 1956-2015). Other opportunistic sightings in the ETOMO study area west of $127.5^{\circ} \mathrm{W}$ include two sightings each of Grey (Eschrichtius robustus), Sperm, Killer (Orcinus orca), and Short-finned Pilot (Globicephala macrorhynchus) Whales; and single sightings of Blue (Balaenoptera musculus) and Sei (B. borealis) Whales (BCCSN, unpublished data 1956-2015). Short-finned Pilot Whales and Pacific White-sided Dolphins have also been reported in offshore waters of Vancouver Island, including within the ETOMO study area (Stacey and Baird 1991; Baird and Stacey 1993; Ford 2014). Other species reported off the west coast of Vancouver Island within $150 \mathrm{~km}$ of shore include Cuvier's Beaked Whale (Ziphius cavirostris), Harbour Porpoise (Phocoena phocoena), and Risso's Dolphin (Ford et al. 2010; Ford 2014).

Our Sperm Whale sighting is one of the farthest offshore sightings made for this area (see Ford 2014); previous sightings occurred east of $128.2^{\circ} \mathrm{W}$ (BCCSN, unpublished data 1956-2015). Opportunistic sightings of Dall's Porpoise $(n=6)$, Pacific White-sided Dolphin $(n=4)$, Fin Whale $(n=2)$, and Humpback Whale $(n$ =1) have been made within the EHV MPA during June, July, and September (BCCSN, unpublished data 19562015). In addition, seismometers deployed near the hydrothermal vent fields from 2003 to 2006 detected Fin and Blue Whale calls every year (Soule et al. 2009). Fin and Blue Whale calls had previously been detected by bottom-mounted hydrophones deployed just south of the ETOMO study area (McDonald et al. 1995). No sightings were made within the EHV MPA during the ETOMO study, but only $220 \mathrm{~km}$ (65 km during nonseismic and $155 \mathrm{~km}$ during seismic operations) of the total $2714 \mathrm{~km}$ of survey effort occurred within the EHV MPA. 
As all sightings during the ETOMO study occurred during non-seismic periods, it is possible that marine mammals actively avoided the area around the operating source, thereby reducing encounter rates. Localized and short-term behavioural responses that include movement away from the sound source have been reported for some cetaceans during seismic surveys (e.g., Richardson et al. 1995; Gordon et al. 2004; Nowacek et al. 2007; Southall et al. 2007). Despite this limitation, our study allowed for the first effort-corrected sighting data to be collected $>150 \mathrm{~km}$ off Vancouver Island and contributes to our understanding of marine mammal and sea turtle distribution and occurrence in offshore waters of British Columbia. Given the limited amount of data currently available, it is not possible to assess whether the EHV MPA is a concentration area for marine mammals; additional surveys would need to be undertaken in and around the area.

\section{Acknowledgements}

This work was conducted under an Incidental Harassment Authorization issued to Lamont-Doherty Earth Observatory (L-DEO) by the United States National Marine Fisheries Service, Office of Protected Resources, and under permits obtained from Fisheries and Oceans Canada. The survey was funded by L-DEO and the National Science Foundation. L-DEO also provided the logistical support for this cruise and the associated monitoring program. I thank the geophysics team from the University of Oregon, who helped make the cruise a success and the dedicated observers (J. Beland, G. Caltavuturo, K. Graham, B. Dawe, M. Myer, and J. Nicolas). The paper was improved by comments from $\mathrm{J}$. Beland, M. Demarchi, B. Koski, and two anonymous reviewers. M. Fitzgerald provided assistance with data processing and mapping. In addition, I thank the Vancouver Aquarium Marine Science Centre and Fisheries and Oceans Canada for providing sightings from the British Columbia Cetacean Sighting Network's database for offshore Vancouver Island, 1956-2015.

\section{Literature Cited}

Baird, R. W., and P. J. Stacey. 1993. Sightings, strandings and incidental catches of short-finned pilot whales, Globicephala macrorhynchus, off the British Columbia coast. Report of the International Whaling Commission, special issue 14: 475-479.

Barlow, J. 2016. Cetacean abundance in the California Current estimated from ship-based line-transect surveys in 1991-2014. Administrative report LJ-12-01. Southwest Fisheries Science Center, National Marine Fisheries Service, La Jolla, California, USA.

Barlow, J., and K. A. Forney. 2007. Abundance and population density of cetaceans in the California Current ecosystem. Fishery Bulletin 105: 509-526.

Becker, E. A., K. A. Forney, D. G. Foley, R. C. Smith, T. J. Moore, and J. Barlow. 2014. Predicting seasonal density patterns of California cetaceans based on habitat models. Endangered Species Research 23: 1-22. https://doi.org/10 .3354/esr00548
Best, B. D., C. H. Fox, R. Williams, P. N. Halpin, and P. C. Paquet. 2015. Updated marine mammal distribution and abundance estimates in British Columbia. Journal of Cetacean Research and Management 15: 9-26.

Bonnell, M. L., C. E. Bowlby, and G. A. Green. 1992. Pinniped distribution and abundance off Oregon and Washington, 1989-1990. Chapter II in Oregon and Washington Marine Mammal and Seabird Surveys. OCS Study MMS 91-0093. Edited by J. J. Brueggeman. Final report prepared by Ebasco Environmental, Bellevue, Washington, and Ecological Consulting Inc., Portland, Oregon, for U.S. Minerals Management Service, Pacific OCS Region, Los Angeles, California, USA.

Ford, J. K. B. 2014. Marine Mammals of British Columbia. Royal British Columbia Museum, Victoria, British Columbia, Canada.

Ford, J. K. B., R. M. Abernethy, A. V. Phillips, J. Calambokidis, G. M. Ellis, and L. M. Nichol. 2010. Distribution and relative abundance of cetaceans in western Canadian waters from ship surveys, 2002-2008. Canadian technical report of fisheries and aquatic sciences 2913. Fisheries and Oceans Canada, Science Branch, Pacific Biological Station, Nanaimo, British Columbia, Canada.

Ganong, J. 2012. TOPP summary of SSM-derived telemetry. Provided by Census of Marine Life Tagging of Pacific Predators Dataset; downloaded from Ocean Biogeographic Information System Spatial Ecological Analysis of Megavertebrate Populations. Accessed 12 June 2017. http://www .iobis.org/mapper.

Gisiner, R., W. S. D. Wilcock, R. E. Thomson, D. C. Soule, B. R. Mate, C. W. Clark, and M. A. Daher. 2009. Vents to whales: a possible trophic link between vent communities and large baleen whales. Abstract. Presented at the $18^{\text {th }}$ Biennial Conference on the Biology of Marine Mammals, 12-16 October 2009, Québec, Quebec, Canada. Society for Marine Mammalogy, Anacortes, Washington, USA.

Gordon, J., D. Gillespie, J. Potter, A. Frantzis, M. P. Simmonds, R. Swift, and D. Thompson. 2004. A review of the effects of seismic surveys on marine mammals. Marine Technology Society Journal 37: 16-34. https://doi.org/10 .4031/002533203787536998

Green, G. A., J. J. Brueggeman, R. A. Grotefendt, C. E. Bowlby, M. L. Bonnell, and K. C. Balcomb, III. 1992. Cetacean distribution and abundance off Oregon and Washington, 1989-1990. Chapter I in Oregon and Washington Marine Mammal and Seabird Surveys. OCS study MMS 91-0093. Edited by J. J. Brueggeman. Final report prepared by Ebasco Environmental, Bellevue, Washington, and Ecological Consulting Inc., Portland, Oregon, for U.S. Minerals Management Service, Pacific OCS Region, Los Angeles, California, USA.

Le Boeuf, B. J., D. E. Crocker, D. P. Costa, S. B. Blackwell, P. M. Webb, and D. S. Houser. 2000. Foraging ecology of northern elephant seals. Ecological Monographs 70: 353-382. https://doi.org/10.1890/0012-9615(2000)070[03 53:FEONES]2.0.CO;2

McAlpine, D. F., S. A. Orchard, K. A. Sendall, and R. Palm. 2004. Status of marine turtles in British Columbia waters: a reassessment. Canadian Field-Naturalist 118: 72-76. https: //doi.org/10.22621/cfn.v118i1.885

McDonald, M. A., J. A. Hildebrand, and S. C. Webb. 1995. Blue and fin whales observed on a seafloor array in the Northeast Pacific. Journal of the Acoustical Society of America 98: 712-721. https://doi.org/10.1121/1.413565 
Nowacek, D. P., K. Bröker, G. Donovan, G. Gailey, R. Racca, R. R. Reeves, A. I. Vedenev, D. W. Weller, and B. L. Southall. 2013. Responsible practices for minimizing and monitoring environmental impacts of marine seismic surveys with an emphasis on marine mammals. Aquatic Mammals 39: 356-377. https://doi.org/10.1578/AM.39.4.2013 .356

Nowacek, D. P., L. H. Thorne, D. W. Johnston, and P. L. Tyack. 2007. Responses of cetaceans to anthropogenic noise. Mammal Review 37: 81-115. https://doi.org/10.1111 /j.1365-2907.2007.00104.x

Pacific Leatherback Turtle Recovery Team. 2006. Recovery strategy for Leatherback Turtles (Dermochelys coriacea) in Pacific Canadian waters. Species at Risk Act recovery strategy series. Fisheries and Oceans Canada, Vancouver, British Columbia, Canada.

Richardson, W. J., C. R. Greene, Jr., C. I. Malme, and D. H. Thomson. 1995. Marine Mammals and Noise. Academic Press, San Diego, California, USA.

Robinson, P. W., D. P. Costa, D. E. Crocker, J. P. GalloReynoso, C. D. Champagne, M. A. Fowler, C. Goetsch, K. T. Goetz, J. L. Hassrick, L. A. Hückstädt, and C. E. Kuhn. 2012. Foraging behavior and success of a mesopelagic predator in the Northeast Pacific Ocean: insights from a data-rich species, the northern elephant seal. PLoS ONE 7: e36728. https://doi.org/10.1371/journal.pone.0036 728

Southall, B. L., A. E. Bowles, W. T. Ellison, J. J. Finneran, R. L. Gentry, C. R. Greene, Jr., D. Kastak, D. R. Ketten, J. H. Miller, P. E. Nachtigall, W. J. Richardson, J. A. Thomas, and P. L. Tyack. 2007. Marine mammal noise exposure criteria: initial scientific recommendations. Aquatic Mammals 33: 411-522. https://doi.org/10.1121/1.4783 461
Soule, D. C., W. S. D. Wilcock, and R. E. Thomson. 2009. Distribution of fin and blue whales above hydrothermal vent fields on the Juan de Fuca Ridge, NE Pacific Ocean. Abstract. Presented at the $18^{\text {th }}$ Biennial Conference on the Biology of Marine Mammals, 12-16 October 2009, Québec, Quebec, Canada. Society for Marine Mammalogy, Anacortes, Washington, USA.

Spaven, L. D., J. K. B. Ford, and C. Sbrocchi. 2009. Occurrence of leatherback sea turtles (Dermochelys coriacea) off the Pacific coast of Canada, 1931-2009. Canadian technical report of fisheries and aquatic sciences 2858. Fisheries and Oceans Canada, Science Branch, Pacific Biological Station, Nanaimo, British Columbia, Canada.

Stacey, P. J., and R. W. Baird. 1991. Status of the Pacific white-sided dolphin, Lagenorhynchus obliquidens, in Canada. Canadian Field-Naturalist 105: 219-232.

Tunnicliffe, V., and R. Thomson. 1999. The endeavour hot vents area: a pilot marine protected area in Canada's Pacific Ocean. Background report. Fisheries and Oceans Canada, Sidney, British Columbia, Canada.

Williams, R., and L. Thomas. 2007. Distribution and abundance of marine mammals in the coastal waters of British Columbia, Canada. Journal of Cetacean Research and Management 9: 15-28.

Wright, A. J., and A. M. Consentino. 2015. JNCC guidelines for minimizing the risk of injury and disturbance to marine mammals from seismic surveys: we can do better Marine Pollution Bulletin 100: 231-239. https://doi.org/10 .1016/j.marpolbul.2015.08.045

Received 7 November 2016

Accepted 9 June 2017 